\title{
The Structure and Hormone Expression of Male Accessory Reproductive Glands of the Sunda Porcupine (Hystrix Javanica)
}

\author{
Teguh Budipitojo $^{1^{*}} \quad$ Synthia Regita Noor Mahesty $^{1} \quad$ Irma Padeta $^{1} \quad$ Linda Miftakhul Khasanah $^{2}$ \\ 1.Department of Anatomy, Faculty of Veterinary Medicine, Universitas Gadjah Mada, Yogyakarta 55281, \\ Indonesia \\ 2.Doctoral Program of Veterinary Science, Faculty of Veterinary Medicine, Universitas Gadjah Mada, \\ Yogyakarta 55281, Indonesia
}

\begin{abstract}
This research was to investigate the histological structure of male accessory reproductive glands of the Sunda porcupine and verify the presence of testosterone and Androgen Binding Protein (ABP) with immunolocalization. The research used three accessory reproductive gland samples of male Sunda porcupine. Tissues were processed using paraffin method and stained with Hematoxylin-Eosin and Immunohistochemistry methods. The histological structure and distribution of testosterone and ABP were analyzed descriptively. This research showed that male accessory reproductive glands of the Sunda porcupine are seminal vesicle, prostate, and bulbourethral glands. The seminal vesicle was lined by simple columnar epithelium, prostate was lined by simple columnar epithelium or simple cuboidal epithelium, and bulbourethral gland was lined by simple cuboidal epithelium. The presence of testosterone was found in adenomere cells of seminal vesicle and prostate glands; and in interstitial tissue of bulbourethral gland. The presence of ABP was detected in the adenomere cells of the bulbourethral gland. The male accessory reproductive glands of Sunda porcupine has been identified which consist of seminal vesicle, prostate, and bulbourethral glands. The immunolocalization of testosterone was found in adenomere cells of seminal vesicle and prostate glands, and ABP was detected in bulbourethral gland.
\end{abstract}

Keywords: Androgen binding protein, Bulbourethral, Hystrix javanica, Prostate, Seminal vesicle, Testosterone DOI: $10.7176 /$ ALST/78-04

Publication date: February $29^{\text {th }} 2020$

\section{Introduction}

Sunda porcupine is classified in the Kingdom of Animalia, Filum Chordata, Mammalia class, Order Rodentia, Family Hystricidae, Genus Hystrix, and Species Hystrix javanica (Duff \& Lawson 2004). Hystrix javanica can be found around the island of Java, Bali, Sumbawa, Flores, Lombok, Madura, Nusa Tenggara, South and Southeast Sulawesi of Indonesia. Indonesian people think the Sunda porcupine is a destructive pest of the community, but some people think the Sunda porcupine's meat has a high potency as a healer for some diseases. Concern about the extinction of Sunda porcupine in Indonesia is increasingly higher, so it is necessary conservation efforts such as collection of reproductive data used to determine the activity and reproductive pattern of Sunda porcupine in Indonesia (Purwaningsih 2013).

According to The International Union for Conservation of Nature (IUCN) of conservation status of Sunda porcupine is included in the category least concern (Lunde \& Aplin 2008). The reproductive system in males is composed of testicles, epididymis, genital accessories glands, duct deferens, urethra, and penis. The genital accessories gland is located along the pelvic of the urethra (Shaw et al. 2017; Bearden et al. 2004). The glands of genital accessories in males are comprised of seminal vesicle glands, prostate glands, bulbourethral glands, and ampules (Akbari et al. 2018; Whitney 2018; Akbari \& Kianifard 2017). The genital accessories gland is specific, which means that not all species have all four of the accessory glands. Plasma seminal is an assortment of fluid produced by the prostate gland, the seminal vesicle gland, and the bulbourethral molar that will be poured into the urethra and will mix with spermatozoa fluid and secretion of ampullary gland, duct deferens, as well as liquids derived from epididymis.

Gland secretion of genital accessories plays a role in the chemical composition and volume of cement. Androgens are necessary for prenatal development and postnatal glands of genital accessories (Murashima et al. 2015), with testosterone as its primary androgen. High level of ABP plays a role of spermatogenesis and sperm maturation in the seminiferous tubules and epididymis, respectively (Ma et al. 2015). The current study aims to determine the type and histological structure of the male accessory reproductive gland of Sunda porcupine, and clarified the expression of testosterone and ABP in the same organs.

\section{Material and methods}

The research used 3 sample organs of the male accessory reproductive glands of the Sunda porcupine taken from Ngawi, East Java, Indonesia. The sample organs used are the seminal vesicle glands, the prostate gland and the bulbourethral gland. According to the licensing of Ethical Clearance Number 326/KEC-LPPT/IX/2015, the genital accessories gland is collected and fixation in the Bouin's solution for 24 hours. The collected tissues of 
male accessory reproductive glands were processed with paraffin method. The sample slides were stained with Haematoxylin Eosin (HE) and immunohistochemical staining methods.

The staining of HE consists of deparaffinization, rehydration, and staining with Harris Haematoxylin and Eosin, dehydration, clearing, and the last stage is the mounting process. The stage of immunohistochemical staining consists of deparaffinization, rehydration, running water, antigens retrieval in microwave, endogenous peroxidase $\left(1 \mathrm{H}_{2} \mathrm{O}_{2}: 9\right.$ methanol), washed with PBS, exclamation blocking, administration of testosterone $(1: 10)$ and ABP (1:500) primary antibodies, HRP Goat Anti-Rabbit IgG, DAB working Solution, running water, dehydration (coverslip), clearing, and the last stage is the mounting process.

\section{Results}

\subsection{The Macroscopic Description of the Male Accessory Gland of Sunda Porcupine}

Macroscopic representation of the genital of the Sunda porcupine gland indicates that the Sunda porcupine has three pairs of genital accessories glands, namely the seminal vesicle gland, the prostate gland, and the bulbourethral gland. The seminal vesicle gland is a pair of glands located on the dorsal surface (Fig. 1) of the urinary vesicles or lateral cauda from the urinary vesicles. The prostate gland is a branched tubuloacinar gland located between the urethra and the seminal portion of the ventral section (Fig. 2), while the bulbourethral gland is a mixed tubuloacinar gland located outside the pelvic cavity next to the caudal the prostate-looting is covered by the musculus ischiocavernosus.

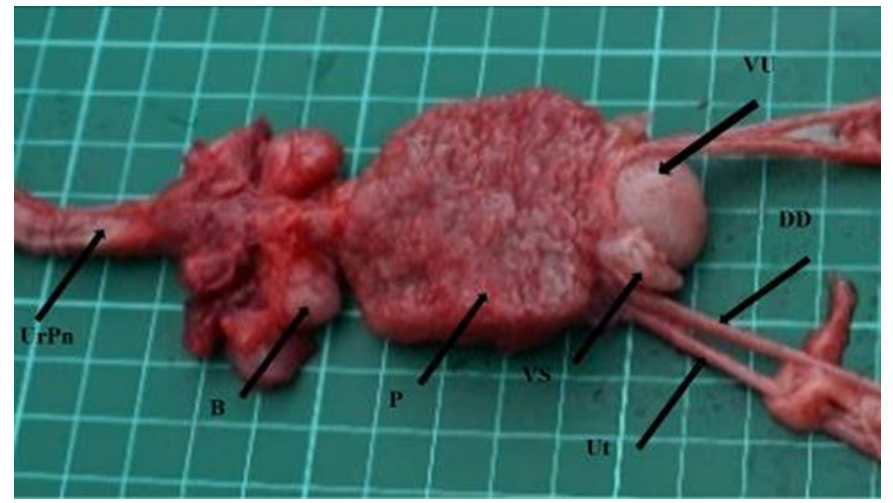

Figure 1. Dorsal view of the reproductive organs of male the Hystrix javanica. Seminal vesicle gland (VS), prostate gland (P), bulbourethral gland (B), ductus deferens (DD), ureter (Ut), bladder (VU), and urethra in the penis $(\mathrm{UrPn})$.

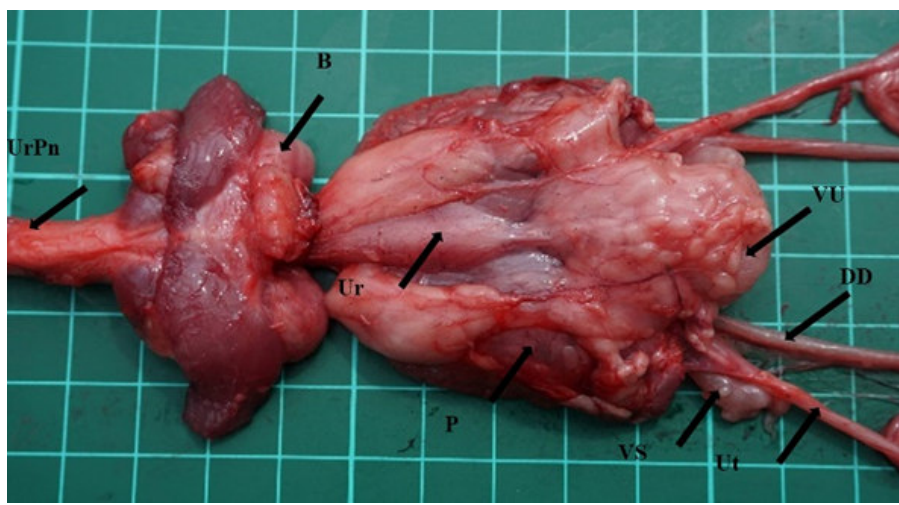

Figure 2. Ventral view of the reproductive organs of male the Hystrix javanica. Vesicle gland (VS), prostate gland (P), bulbourethral gland (B), ductus deferens (DD), ureter (Ut), urethra (Ur), bladder (VU), and urethra in the penis (UrPn).

\subsection{Histology Structure of Male Accessory Gland of Sunda Porcupine}

Hematoxylin Eosin staining, results in an overview of the histological structures of the seminal vesicle gland, the prostate gland, and the bulbourethral gland. Figure 3 shows the seminal vesicle gland consisting of four lobes with each lobe surrounded by thick smooth muscle. 


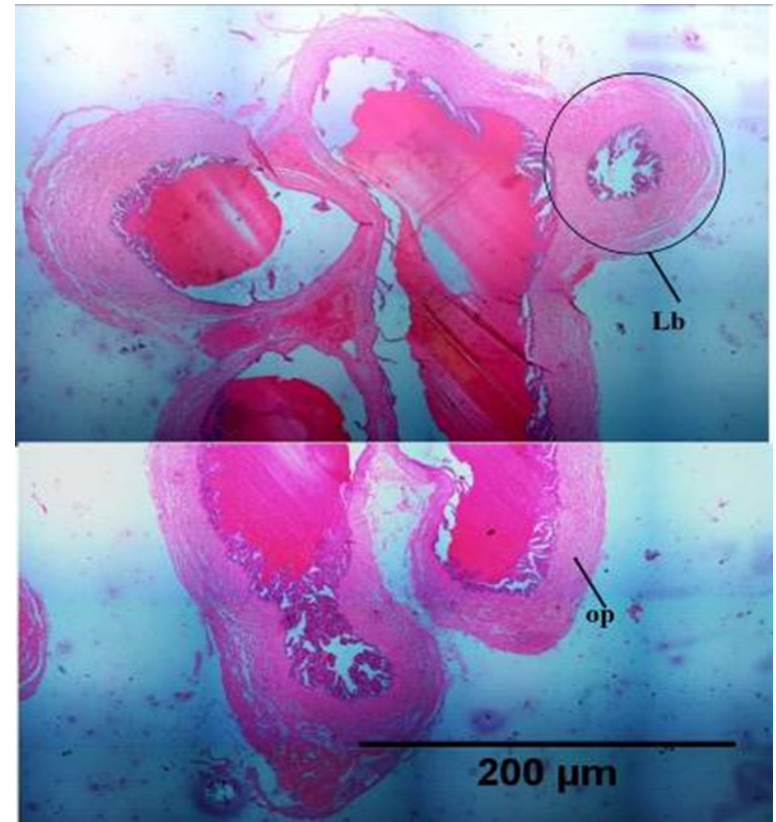

Figure 3. Histological photographs of whole parts of the Hystrix javanica's seminal vesicle gland (HE). It shows that the seminal vesicle gland consists of four lobules, each with glandular lobule surrounded by thick smooth muscle capsules. $\mathrm{Lb}=$ lobules; op= capsule.

The seminal vesicle gland consists of several layers namely lamina epithelialis mucosae, lamina propiasubmucosa, the tunica muscularis, and the tunica adventitia (Fig. 4A). The lamina epithelialis mucosae consist of epithelium columnar simplex with varying height, whereas lamina propia-submucosa is composed by loose collagenous connective tissue (Fig. 4C). The musculoskeletal tunic in this gland is divided into two laminas namely lamina muscularis circular internal and lamina longitudinal external (Fig. 4B). Lamina on the tunica muscularis is dominated by smooth muscles with difficult boundaries, while in tunica adventitia are composed by connective tissue and blood vessels (Fig. 4D). The seminal vesicle gland of the Sunda porcupine is included in the serous gland type as it has a rounded cell nucleus and is located in the center (Fig. 4C).

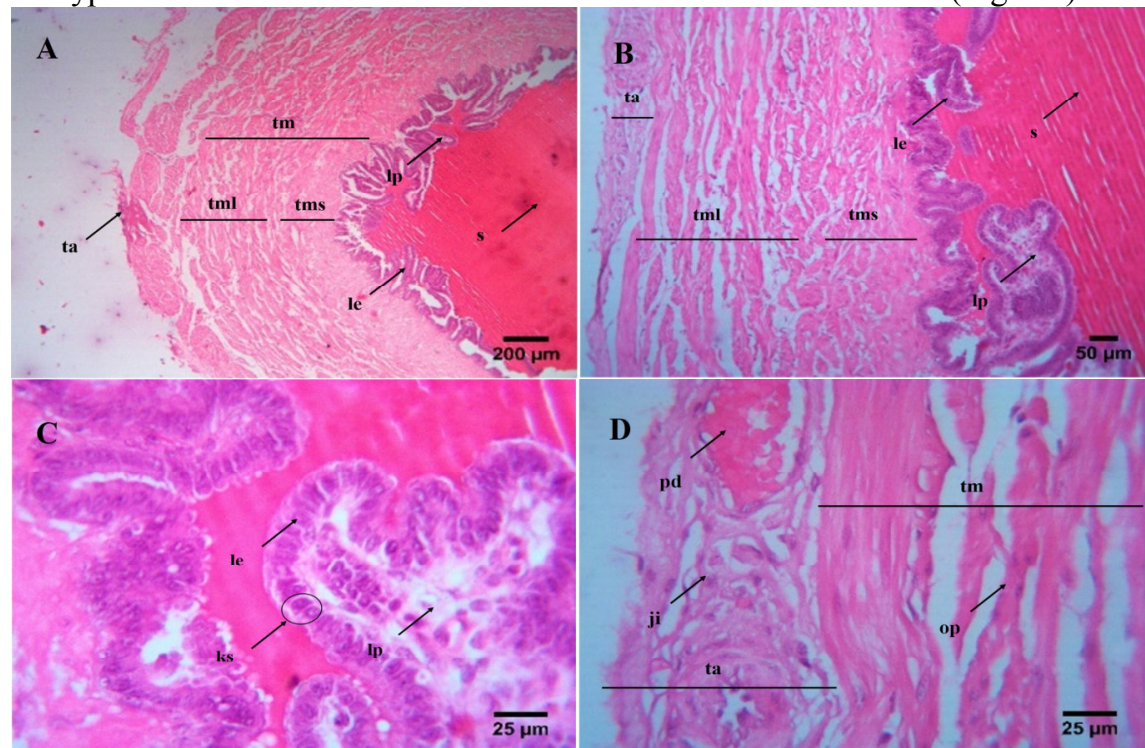

Figure 4. Histological photographs of the Hystrix javanica's seminal vesicle gland (HE). (A) shows that the seminal vesicle gland consists of several layers, including the lamina epithelialis mucosa (le), lamina propriasubmucosa (lp), tunica muscular (tm), and tunica adventitia (ta). (B) and (C) indicate the lamina epithelialis mucosa (le) is simple columnar epithelium, whereas the lamina propria-submucosa (lp) is composed of loose collagenous connective tissue. The tunica muscular (tm) in this gland is divided into two lamina which include the internal circulatory lamina muscular (tms) and external longitudinal lamina muscular (tml). (D) indicates that the lamina in the tunica muscular is dominated by smooth muscle with a boundary that is difficult to distinguish, while the tunica adventitia is composed of connective tissue and blood vessels. (C) also shows that the seminal vesicle gland is a type of serous gland $(\mathrm{ks})$. 
Figure 5 shows that the prostate gland lobe has two parts, the corpus and the portions are disseminated. The dissemination portion is part of the prostate gland located around the urethra. Portions of the prostate gland are urethra, residual duct deference, and seminal vesicle glands. The lobe of the prostate gland is each compiled by several lobules of the glands. The lobules in the corpus are composed by the adenomere of the prostate gland and the part is composed by the excretory duct surrounded by the fibro myoelastic capsule, which composed of collagen connective tissues, elastic tissues and smooth muscles.

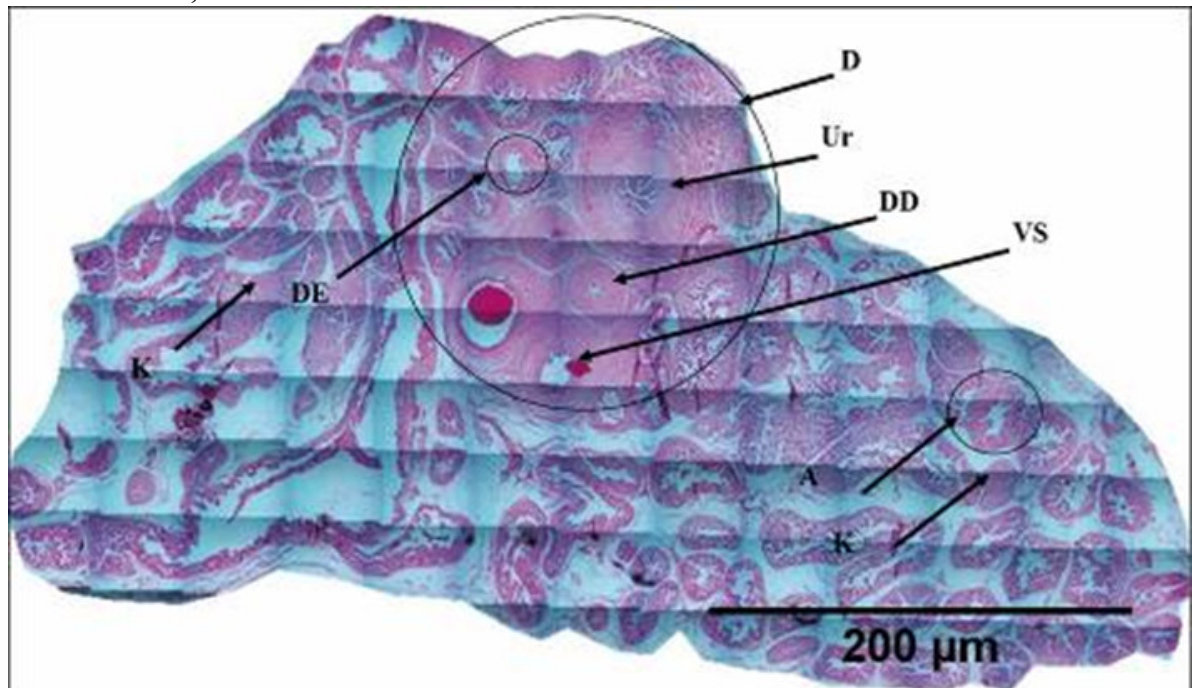

Figure 5. Histological photographs of whole parts of the Hystrix javanica's prostate gland (HE). It shows that the lobe of the prostate gland has two parts: among them are the corpus (K) and the disseminated part (D). The disseminated part of the prostate gland includes the urethra (Ur), ductus deferens (DD), and seminal vesicle gland (VS). The lobules in the corpus are composed of the adenomere (A) of the prostate gland and the excretory duct (DE) located in the disseminated part.

The adenomere of the prostate gland is composed of several layers; lamina epithelialis mucosae, lamina propia-submucous, tunica muscularis, and tunica adventitia (Fig. 6A and 6B). The Lamina epitelialis mucosa on the epithelium of the prostate gland is in the form of a columnar simplex, or a cuboid simplex epithelium (Fig. 6C and 6D). The Lamina propia-submucosa contains connective tissue and tunica muscularis are composed of smooth muscles (Fig. 6C). The Tunica adventitia consists of connective tissues and blood vasa. (Fig. 6D).

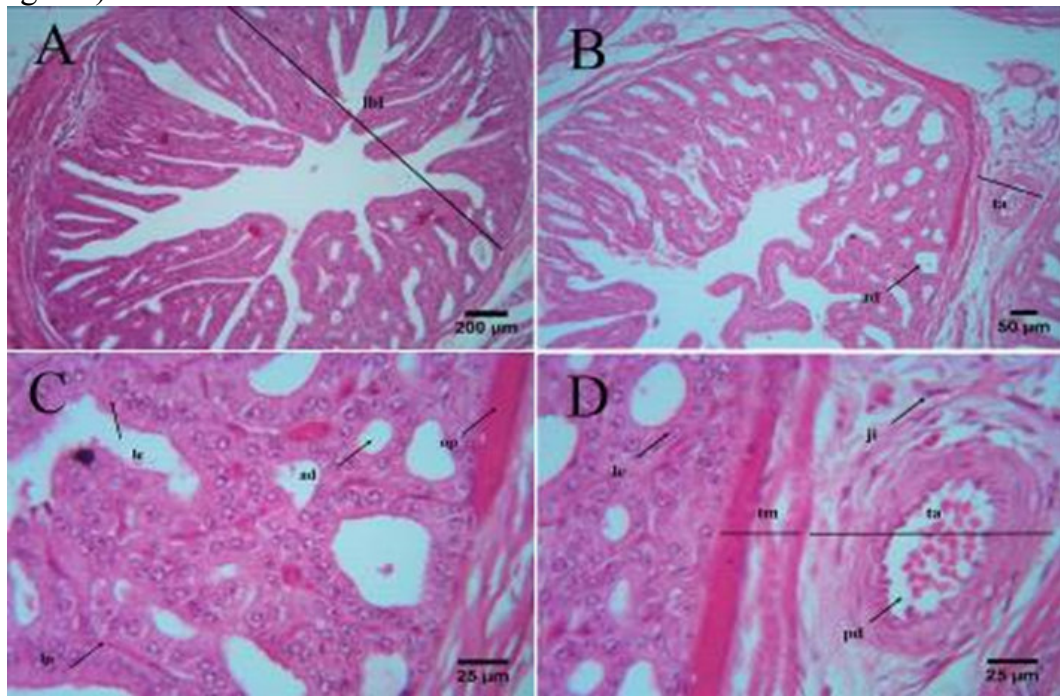

Figure 6. Histological photographs of the Hystrix javanica's corpus part of the prostate gland (HE). (A) and (B) show the prostate glands with lobules (lbl) in the corpus part are composed of the adenomere (ad). (C) and (D) show the adenomere of the prostate gland is composed of the lamina epithelialis mucosa (le), lamina propriasubmucosa (lp), tunica muscular (tm), and tunica adventitia (ta). The lamina epithelialis mucosa (le) is in the form of simple columnar epithelium or simple cuboidal epithelium. The lamina propria-submucosa (lp) contains connective tissue, whereas the tunica muscular is composed of smooth muscle. The tunica adventitia is composed of connective tissue (ji) and blood vessels (pd).

Excretory duct of the prostate gland is composed of several layers namely lamina epithelialis mucosae, 
lamina propria-submucosa, tunica muscularis and tunica adventitia (Fig. 7A). Lamina epitelialis mucosa has the same epithelium as the adenomere, which is the epithelium columnar simplex or epithelium cuboid simplex (Fig. 7B). The Lamina propia-submucosa contains connective tissue and muscularis tunic composed of smooth muscles (Fig. 7B). The Tunica adventitia consists of connective tissues and blood vessels. The prostate gland in the Sunda porcupine is included in the serous gland type as it has a rounded cell nucleus and is located in the center.
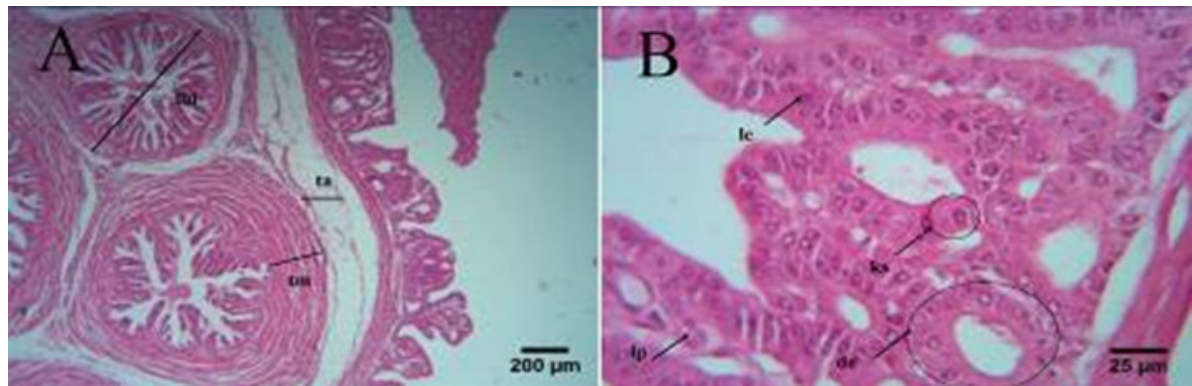

Figure 7. Histological photographs of the Hystrix javanica's disseminated part of the prostate gland (HE). The prostate gland is composed of lobules $(\mathrm{lbl})$ and the excretory duct $(\mathrm{de})$. (A) and (B) shows the adenomere of the

prostate gland is composed of the lamina epithelialis mucosa (le), lamina propria-submucosa (lp), tunica muscular (tm), and tunica adventitia (ta). The lamina epithelialis mucosa (le) is in the form of simple columnar epithelium or simple cuboidal epithelium. (B) also shows that the prostate gland is a type of serous gland (ks).

The last male gland is the bulbourethral gland. The gland is wrapped by fibroelastic capsule consisting of smooth muscles, connective tissues, and muscular skeletal (Fig 8). A single lobe of the bulbourethral gland (Fig. 9A) consists of a lobule that is bordered by an interlobular septum that contains connective tissues and each lobule there are some adenomeres surrounded by fibrous connective tissues (Fig. 9B and 9C). Image of 9D suggests that a bulbourethral gland adenomere is surrounded by a simplex cuboid epithelium. Bulbourethral glands of the Sunda porcupine belong to the mucous gland type because it has a flat-shaped cell nucleus and is located on the edge (Fig. 9D).

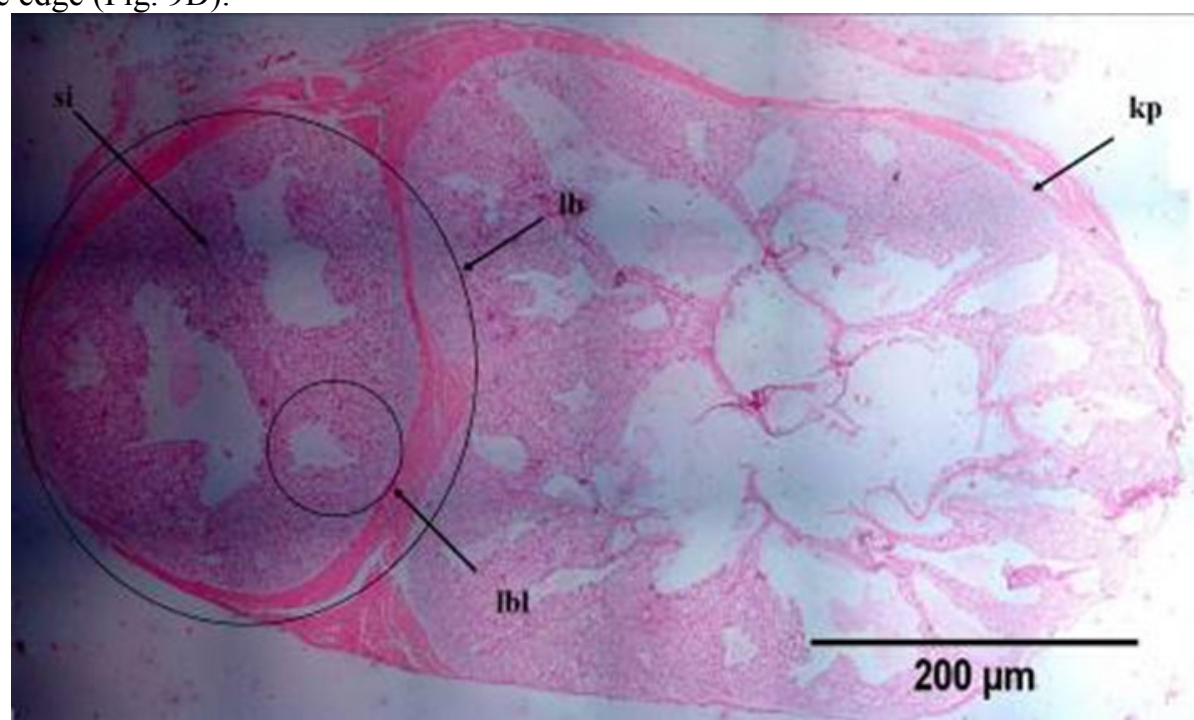

Figure 8. Histological photographs of the Hystrix javanica's bulbourethral gland (HE). It show the bulbourethral gland consists of two lobes (lb) with each glandular lobe surrounded by fibroelastic capsules (kp). Each lobe of the bulbourethral gland consists of lobules (lbl) bounded by the interlobular septum (si). 


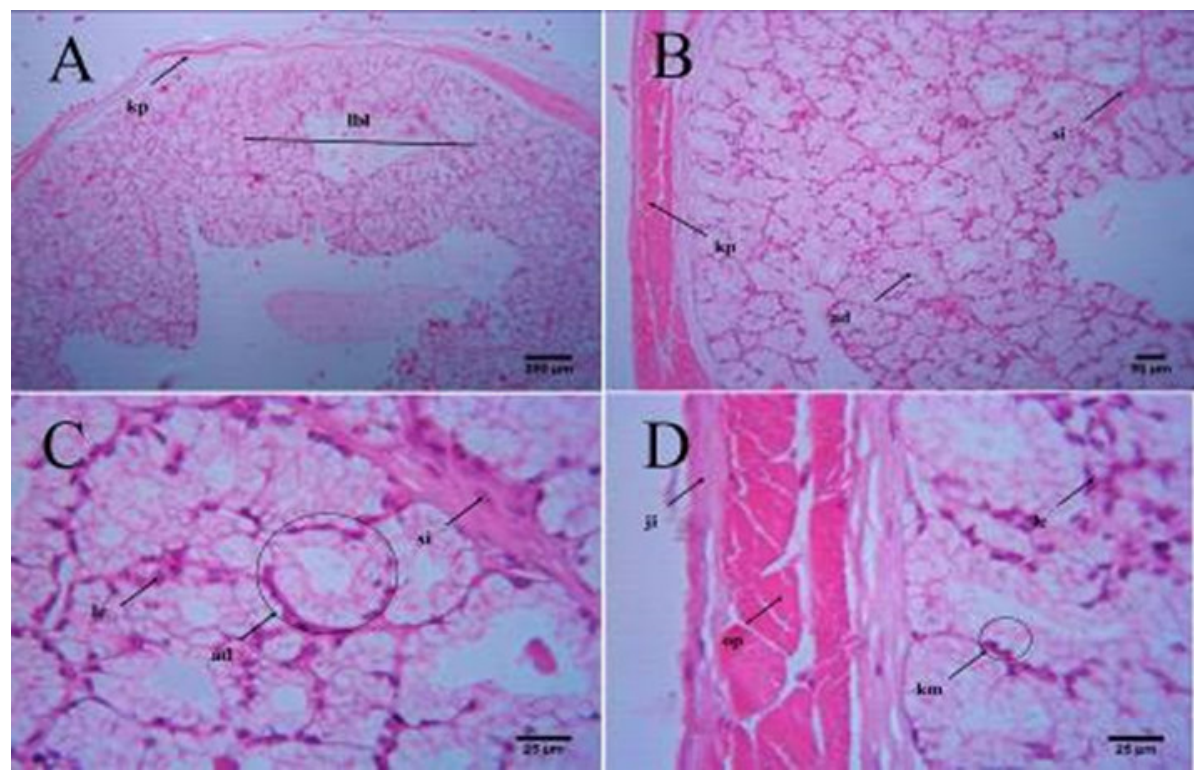

Figure 9. Histological photographs of the Hystrix javanica's bulbourethral gland (HE). (A) shows the lobe surrounded by fibroelastic capsules (kp). (B) One lobe of the bulbourethral gland consists of lobules (lbl) bounded by the interlobular septum (si). (C) shows the adenomere (ad) is surrounded by simple cuboidal epithelium (le). (D) shows the fibroelastic capsules which consist of smooth muscle (op), connective tissue (ji), and skeletal. The bulbourethral gland is a type of mucous gland (km).

\subsection{Distribution of Testosterone and ABP}

The result of immunohistochemistry staining with testosterone antibodies suggests that there is immunized cytoplasm in the adenomere cells of the seminal vesicle gland (Fig. 10A), cytoplasm of the adenomere of the prostate gland (Fig. 10B), and the interstitials tissue of the bulbourethral gland (Fig. 10C). These immunoreactive cells are characterized by brown color, while the purple color comes from the counterstain using Harris Haematoxylin. The result of immunohistochemical staining with ABP/SHBG polyclonal antibodies suggests that only in the bulbourethral gland shows the immunoreactive cells of the adenomere cytoplasm (Fig. 10D).

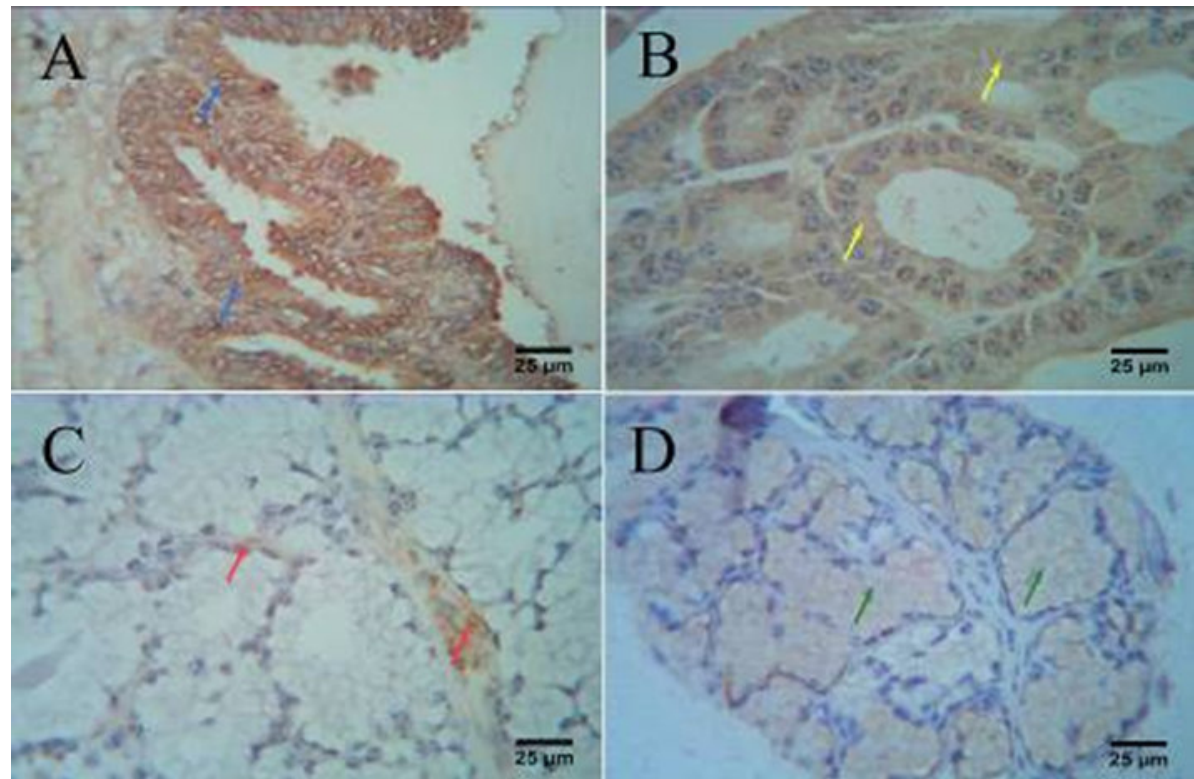

Figure 10. The expression of testosterone and ABP in the male accessory reproductive glands of the Hystrix javanica (IHC). (A) shows the immunoreactive cells against testosterone antibodies in the seminal vesicle gland characterized by staining of the adenomer cytoplasm. (B) shows the immunoreactive cells against testosterone antibodies in the prostate. (C) shows the immunoreactive cells against testosterone antibodies in the bulbouretral gland. (D) shows the immunoreactive cells against ABP antibodies in the bulbouretral gland. 


\section{Discussion}

Macroscopic evaluation on Sunda porcupine gland indicates that there have three pairs of genital accessory glands, namely the seminal vesicle, the prostate gland, and the bulbourethral gland. Akbari et al. (2018) explained that the seminal vesicle gland located on the dorsal surface or lateral cauda of vesica urinaria. This indicates that there are differences in the gland type of genital accessories in the Sunda porcupine with other Rodentia, but it has a similarity to the location of the accessory's gland. The difference is the Sunda porcupine doesn't have an ampulla gland, while other Rhodesians have it.

HE staining results in an overview of the histological structures accessories glands. The seminal vesicle gland produces a yellowish, viscous liquid that serves as an active substance for sperm motility (Eroschenko 2008). The seminal vesicle gland consists of four lobes with each lobe surrounded by thick smooth muscle capsule. The seminal vesicle gland consists of several layers namely lamina epithelialis mucosae, lamina propria-submucosa, tunica muscular, and tunica adventitia. The lamina epitelialis mucosae consist of epithelium columnar simplex with varying height, whereas on the lamina propia-submucosa is composed by loose collagen connective tissue. The lamina on the tunica muscularis is dominated by smooth muscles with difficult boundaries, while in the tunica adventitia composed by connective tissue and blood vessels (Khojasteh et al. 2014). According to Treuting et al. (2018), the seminal vesicle gland of other Rodentia belongs to the serous gland type because it has a rounded cell nucleus and is located in the center of the cells, it shows similarities to the Sunda porcupines.

The prostate gland is a small branching gland that produces secretions and is slightly acidic. The results obtained from the observation that the prostate gland in Sunda porcupine has a similar structure to Rodentia, because it has a pair of lobes, namely the ventral lobe and dorsolateral lobe, but the porcupine does not have anterior lobes or coagulating glands (Neill 2006). The prostate gland lobe has two parts namely the corpus and the disseminated part. Disseminated is part of the prostate gland around the urethra. Disseminated part of the prostate gland is the urethra, the remaining deferens ducts, and the seminal vesicle gland. The lobes of the prostate gland are each composed by several glands' lobules (Ross \& Pawlina 2011).

The histological structure of the prostate gland in the Sunda porcupine has a difference with other rodents. The difference is in the disseminated part of the lamina epithelial mucosa of the excretory duct of the Sunda porcupine prostate gland in the form of the epithelium columnar simplex or cuboid simplex epithelium, whereas in the other Rodentia is pseudo complex epithelium (Eroschenko 2008). According to Treuting et al. (2018) the prostate gland in other rodents is included in the type of serous gland because it has a rounded cell nucleus and is located in the middle of adenomere cells, this shows similarities in the Sunda porcupine so that it can be said that the type of prostate gland of Sunda porcupine gland is a type of serous gland.

The last male accessory genital gland is the bulbourethral gland. The bulbourethral gland is a mixed tubuloacinar gland capable of producing mixed secretions from mucous and seromucous material (Treuting et al. 2018). The bulbourethral gland adenomere is surrounded by a cuboid simplex epithelium (Scudamore 2014). This shows the similarity of the histological structure of the bulbourethral gland in Sunda porcupines with other rodents. According to Treuting et al. (2018) the bulbourethral glands in other rodents are included in the mucosal gland type because they have a flat cell nucleus and are located on the edge, this shows similarities in the Sunda porcupine so that it can be said that the type of bulbourethral gland is a type of mucosal gland.

The results of immunohistochemical staining with testosterone antibodies indicate that there are immunoreactive cells in the cytoplasm of the seminal vesicle gland adenomere cells, cytoplasm of the prostate gland adenomere cells, and interstitial tissues of the bulbourethral gland. Dihydrotestosterone (DHT) is an active form of testosterone that belongs to the strong androgenic metabolite (Chaves et al. 2011); and it's important for normal male genital, prostatic development, promote the growth and survival of prostate cells (Anawalt 2017; Tan et al. 2015; Zhou et al. 2015).

Androgen Binding Proteins is testicular glycoproteins that bind androgens with high affinity (del Mar Grasa et al. 2017; Laurent et al. 2016). ABP in the testis Rodentia is synthesized by Sertoli cells and is secreted into the seminiferous tubule lumen and into other vascular compartments. The results of immunohistochemical staining with polyclonal ABP/SHBG antibodies showed that only in the bulbourethral gland showed immunoreactive cells that were marked with a brownish color in the cytoplasm of adenomere cells.

\section{Conclusion}

The results of this study indicate that the male accessories glands of Sunda porcupine (Hystrix javanica) consists of seminal vesicles gland, prostate gland and bulbourethral gland. Seminal vesicle gland was lined by simplex columnar epithelium, prostate gland was lined by simplex columnar epithelium or simplex cuboid, and bulbourethral gland was lined by simplex cuboid epithelium. Immunohistochemical staining results show that testosterone is found in the adenomere cells of the seminal vesicle gland, the adenomere cells of the prostate gland, and the interstitial tissues of the bulbourethral gland. The ABP is detected in the cytoplasm of adenomere cells of the bulbourethral gland, but not seminal vesicle and prostate glands. 


\section{References}

Akbari, G \& Kianifard, D. (2017). Anatomy, histology and histochemistry of accessory sex glands in male Persian squirrel (Sciurus anomalus). Italian Journal of Anatomy and Embryology, 122, 17-26

Akbari, G., Babaei, M., Kianifard, D., \& Mohebi, D. (2018). The gross Anatomy of the male reproductive system the European Hedgehog (Erinaceus Europaeus). Folia Morphol, 77, 36-43

Anawalt, B. D. (2017). Is Dihydrotestosterone a Classic Hormone? Endocrine reviews, 38, 170

Bearden, H.J., Fuquay, J.W., \& Willard, S.T. (2004). Applied Animal Reproduction. Pearson Education, United States of America. pp. 22-35

Chaves, E.M., Aguilera-Merlo, C., Filippa, V., Mohamed, F., Dominguez, S., \& Scardapane, L. (2011). Anatomical, Histological and Immunohistochemical Study of the Reproductive System Accessory Glands in Male Viscacha (Lagostomus maximus maximus). Anatomia Histologia Embryologia, 40, 11-20

del Mar Grasa, M., Gulfo, J., Camps, N., Alcalá, R., Monserrat, L., Moreno-Navarrete, J. M., Ortega, F.J., Esteve, M., Remesar, X., Fernandez-Lopez, J.A., Fernández-Real, J. M., \& Alemany, M. (2017). Modulation of SHBG binding to testosterone and estradiol by sex and morbid obesity. European journal of endocrinology, 176, 393-404

Duff A., \& Lawson A. (2004). Mammals of the World a Checklist. Yale University Press, London. pp. 253-259

Eroschenko, V.P. (2008). diFIORE'S Atlas of Histology with Fuctional Correlations. Lippincott Williams \& Wilkins, United States of America. pp. 409-436.

Khojasteh, B.S.M., Rodbari, F., Tabrizi, H.F., \& Delashoub, M. (2014). Histological study of Prostate and Vesicular Glands in Eartern European hedgehog (Erinaceous concolor). Biology and Medicine, 6, 1-3

Laurent, M. R., Hammond, G. L., Blokland, M., Jardí, F., Antonio, L., Dubois, V., Khalil, R., Sterk, S.S., Gielen, E., Decallonne, B., Carmeliet, G., Kaufman, J.M., Fiers, T., Huhtaniemi, I.T., Vanderschueren, D., \& Claessens, F. (2016). Sex hormone-binding globulin regulation of androgen bioactivity in vivo: validation of the free hormone hypothesis. Scientific reports, 6, 35539

Lunde, D. \& Aplin, K. (2008). Hystrix javanica. The IUCN Red List of Threatened Species. Version 2014.3. www.iucnredlist.org. accessed on 10th October 2018

Ma, Y., Yang, H. Z., Xu, L. M., Huang, Y. R., Dai, H. L., \& Kang, X. N. (2015). Testosterone regulates the autophagic clearance of androgen binding protein in rat Sertoli cells. Scientific reports, 5, 8894

Murashima, A., Kishigami, S., Thomson, A., \& Yamada, G. (2015). Androgens and mammalian male reproductive tract development. Biochimica et Biophysica Acta (BBA)-Gene Regulatory Mechanisms, 1849, 163-170

Neill, J.D. (2006). Knobil and Neill's Physiology of Reproduction Vol 1 (3rd Ed). Elsevier Academic Press, United States of America. pp. 1149-1172

Purwaningsih, E. (2013). The first report of new species: Trichuris landak n. sp. Asian Pacific journal of tropical biomedicine, 3, 85-88

Ross, M.H., \& Pawlina, W. (2011). Histology A Text and Atlas. Lippincott Williams \& Wilkins, New York. pp. $728-756$

Scudamore, C.L. (2014). A Practical Guide to the Histology of the Mouse. Wiley Blackwell, United States of America. pp. 97-105

Shaw, K., Nandi, K., Ganguly, R., \& Roy, C. (2017). Role of Catharanthus roseus Linn.(Nayantara) on sperm count and serum testosterone level of adult male albino rat. World Journal of Pharmaceutical Research, 6 , $1087-1096$

Tan, M. E., Li, J., Xu, H. E., Melcher, K., \& Yong, E. L. (2015). Androgen receptor: structure, role in prostate cancer and drug discovery. Acta Pharmacologica Sinica, 36, 3

Treuting, P.M., Dintzis, S.M., \& Montine, K.S. (2018). Comparative Anatomy and Histology: A Mouse, Rat, and Human Atlas. Academic Press, United States of America. pp. 335-358

Whitney, K. M. (2018). Male Accessory Sex Glands. Academic Press, USA. pp. 579-586

Zhou, Y., Bolton, E. C., \& Jones, J. O. (2015). Androgens and androgen receptor signaling in prostate tumorigenesis. Journal of Molecular Endocrinology, 54, 15-29 